\title{
INTERNATIONAL JOURNAL OF THE SOCIOLOGY OF LANGUAGE
}

GENERAL EDITOR

Alexandre Duchêne

University of Fribourg, Switzerland

\section{ASSOCIATE EDITORS}

Sibonile Ellece

University of Botswana, Botswana

Ruanni Tupas

University College London, United Kingdom

Virginia Unamuno

CONICET-Universidad de San Martín, Argentina

Jacqueline Urla

University of Massachusetts, Amherst, USA

\section{'SINGLES' EDITOR}

Florian Coulmas

University of Duisburg-Essen, Germany

\section{GENERAL EDITOR EMERITUS}

Ofelia García

The Graduate Center, City University of New York

FOUNDING EDITOR (1974-2015)

Joshua A. Fishman ${ }^{\dagger}$

\section{DE GRUYTER MOUTON}


EDITORIAL BOARD 2016-2020

E. Annamalai

University of Chicago, USA

Yoshiyuki Asahi

National Institute for Japanese

Language, Tokyo

Matthias Brenzinger

University of Cape Town, South Africa

David M. Bunis

Hebrew University of Jerusalem, Israel

Serafín Coronel-Molina

Indiana University, USA

Nikolas Coupland

Copenhagen University, Denmark and

Cardiff University, UK

Paulin Djité

Université FHB, Côte d'Ivoire

Rosalie Finlayson

University of South Africa UNISA

Nelson Flores

University of Pennsylvania, USA

Federica Guerini

Università degli Studi di Bergamo,

Italy

Rainer Enrique Hamel

U. Autónoma Metropolitana, Mexico

Patrick Heinrich

Ca' Foscari University of Venice, Italy

Christine Hélot

University of Strasbourg, France

Francis M. Hult

Lund University, Sweden

Herbert Igboanusi

University of Ibadan, Nigeria

Kendall King

University of Minnesota, USA
Joseph Lo Bianco

University of Melbourne, Australia

Leketi Makalela

University of the Witwatersrand,

Johannesburg, South Africa

John Maher

Intern. Christian University, Japan

Francisco Moreno-Fernández

University of Alcalá, Spain

Finex Ndhlouvu

University of New England, Armidale,

Australia

Ricardo Otheguy

Graduate Center, CUNY, USA

Rakhmiel Peltz

Drexel University, USA

Mark Sebba

Lancaster University, UK

Elana Shohamy

Tel Aviv University, Israel

Dick Smakman

Leiden University, the Netherlands

Mauro Tosco

University of Turin, Italy

Guadalupe Valdés

Stanford University, USA

Li Wei

University College London, UK

Xu Daming

University of Macau

Kutlay Yağmur

Tilburg University, the Netherlands 
ABSTRACTED/INDEXED IN Baidu Scholar · BDSL Bibliographie der deutschen Sprach- und Literaturwissenschaft · Cabell's Directory · CNKI Scholar (China National Knowledge Infrastructure) · CNPIEC: cnpLINKer - Dimensions - EBSCO (relevant databases) - EBSCO Discovery Service · ERIH PLUS (European Reference Index for the Humanities and Social Sciences) · Gale/Cengage . Genamics JournalSeek · Google Scholar · IBR (International Bibliography of Reviews of Scholarly Literature in the Humanities and Social Sciences) · IBZ (International Bibliography of Periodical Literature in the Humanities and Social Sciences) - International Bibliography of the Social Sciences (ProQuest) - J-Gate · JournalGuide · JournalTOCs · KESLI-NDSL (Korean National Discovery for Science Leaders) · Linguistic Bibliography · Linguistics Abstracts Online · Microsoft Academic · MLA International Bibliography · Naviga (Softweco) · Norwegian Register for Scientific Journals, Series and Publishers · OLC Linguistik · Primo Central (ExLibris) · ProQuest (relevant databases) · Publons · QOAM (Quality Open Access Market) · ReadCube · SCImago (SJR) - SCOPUS · Sherpa/ RoMEO · Summon (Serials Solutions/ProQuest) · TDNet · Ulrich's Periodicals Directory/ulrichsweb . WanFang Data $\cdot$ WorldCat (OCLC)

The publisher, together with the authors and editors, has taken great pains to ensure that all information presented in this work reflects the standard of knowledge at the time of publication. Despite careful manuscript preparation and proof correction, errors can nevertheless occur. Authors, editors and publisher disclaim all responsibility for any errors or omissions or liability for the results obtained from use of the information, or parts thereof, contained in this work.

ISSN 0165-2516 · e-ISSN 1613-3668

All information regarding notes for contributors, subscriptions, Open access, back volumes and orders is available online at www.degruyter.com/ijsl

RESPONSIBLE EDITORS Alexandre Duchêne, University of Fribourg, Institute of Multilingualism, Rue de Morat 24, 1700 Fribourg, Switzerland, E-mail: alexandre.duchene@unifr.ch;

Florian Coulmas, IN-EAST Institute of East Asian Studies, University of Duisburg-Essen, 47048 Duisburg, Germany, E-mail: florian.coulmas@uni-due.de

JOURNAL MANAGER Katharina Kaupen, De Gruyter, Genthiner Straße 13, 10785 Berlin, Germany, Tel: +49 (0)30 260 05-423, Fax: +49 (0)30 260 05-250.

Email: katharina.kaupen@degruyter.com

RESPONSIBLE FOR ADVERTISEMENTS Katharina Kaupen, De Gruyter, Genthiner Straße 13, 10785 Berlin, Germany, Tel.: +49 (0)30 $26005-170$,

Email: anzeigen@degruyter.com

(C) 2020 Walter de Gruyter GmbH, Berlin/Boston

TYPESETTING TNQ Technologies, Chennai, India.

PRINTING Franz X. Stückle Druck und Verlag e.K., Ettenheim

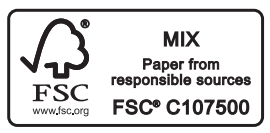




\section{Contents}

\section{Singles Issue: Multiplicity and Stratification of Languages and their Speakers}

Issue Editor: Florian Coulmas

Ofelia García and Rebecca Walter

Florian Coulmas: IJSL's amplified forked voice -1

Louisa Buckingham

Ethnolinguistic diversity in New Zealand: A socioeconomic analysis -5

Ryan Szpiech, Joshua Shapero, Andries W. Coetzee, Lorenzo García-Amaya, Paulina Alberto, Victoria Langland, Ellie Johandes and Nicholas Henriksen Afrikaans in Patagonia: Language shift and cultural integration in a rural immigrant community — 33

Víctor Fernández-Mallat

Contrasting language attitudes: The case of Spanish in Basel -55

Juan Jiménez-Salcedo

La compleja cohabitación jurídica del catalán y el francés en el Rosellón: análisis de políticas lingüísticas en el ámbito educativo — 77

Tammy Jandrey Hertel and Hilary Barnes

Language use and attitudes toward Kaqchikel and Spanish in San Marcos La Laguna, Guatemala — 95

Hassan Belhiah, Mohamed Majdoubi and Mouna Safwate Language revitalization through the media: A case study of Amazigh in Morocco - 121

\section{Book Review}

Xiaofang Yao

Alastair Pennycook. 2018. Posthumanist applied linguistics — 143 